\title{
EFFECT OF PLACEMENT OF FERTILIZER AND SPRINKLER IRRIGATION ON THE DEVELOPMENT OF SPRING CEREALS ON THE BASIS OF ROOT INVESTIGATIONS
}

\author{
Jorma Kähäri and PAavo Elonen \\ University of Helsinki, Department of Agricultural Chemistry
}

Received January 25, 1969

Two effective methods have been established recently in order to diminish on the clay soils of South Finland the injuring of cereals by spring and early summer droughts: placement of fertilizer and sprinkler irrigation (Pohjanheimo and Heinonen 1960, HeinoNen and Nieminen 1961, Larpes 1966, 1967, Nieminen et al, 1967, Elonen et al, 1967, Aura 1967). The former method is already widely adopted by farmers, but only a few of them have accepted the latter.

In the sprinkler irrigation technique as well as in the technique of fertilizer placement there are, however, many unsolved problems, e. g. which is the best mutual position for fertilizer and seed under Finnish conditions. Questions of this kind cannot be solved without extending the investigations also to the underground parts of plants, towards which the irrigation and placement of fertilizer is primarily directed.

The purpose of the present work was to study the development of the root system of spring cereals during the growing season, the effect of fertilizer placement and irrigation on the correlation between the yield and the root system, and on the distribution of the root system in the ploughed layer.

\section{Experimental}

F i e l d t ria l s. The root investigation was performed in the neighbourhood of Helsinki in connection with two large field trials, adjacent to each other. The compelete results of these trials will be published later.

In trial 1, started on May 10th, the test crop was spring wheat "Svenno». Finnish compound fertilizer (15-20-15) was applied according to the following plan: 1. no fertilizer, 2. $600 \mathrm{~kg} / \mathrm{ha}$ as a surface dressing, $3.600 \mathrm{~kg} / \mathrm{ha}$ placed in rows at a distance of $12 \mathrm{~cm}$ by 
a Finnish »MK-kombi»-fertilizer drill, 4. $600 \mathrm{~kg} / \mathrm{ha}$ placed in rows at a distance of $18 \mathrm{~cm}$ by a Mc Cormick machine. The fertilizer was placed at a depth of $8 \mathrm{~cm}$.

In trial 2, established on May 12th, spring wheat "Svenno" and barley "Ingrid» were used as test crops. $750 \mathrm{~kg} / \mathrm{ha}$ of compound fertilizer (8-13-9) was either applied to the soil surface or placed with a "Juko»-fertilizer drill with a row distance of $15 \mathrm{~cm}$. The placement depth was $8 \mathrm{~cm}$. The surface dressing was performed with the plastic fertilizer tubes outdrawn from the coulters. In the same way $400 \mathrm{~kg} /$ ha of calcium nitrate $(15.5 \% \mathrm{~N})$ was applied on shoots on June 15th. The root studies were carried out on plots which were not irrigated, and on plots which were irrigated on June 15th and June 21st with $30 \mathrm{~mm}$ of drainage ditch water at both times.

Soil and we a ther conditions. Certain physical and chemical characteristics of the experimental soil were as follows:

\begin{tabular}{|c|c|c|c|c|c|c|c|c|c|c|}
\hline \multirow{2}{*}{$\begin{array}{l}\text { Depth } \\
\mathrm{cm}\end{array}$} & \multicolumn{3}{|c|}{ Particle size fractions $\%$} & \multirow{2}{*}{$\begin{array}{c}\text { Org. C } \\
\%\end{array}$} & \multirow[t]{2}{*}{$\mathrm{pH}$} & \multicolumn{5}{|c|}{ Exchangeable cations me $/ 100 \mathrm{~g}$ Bray 1 test } \\
\hline & $<2 \mu$ & -20 & $20 \mu$ & & & $\mathrm{Ca}^{++}$ & $\mathrm{Mg}^{++}$ & $\mathrm{K}^{+}$ & $\mathrm{Na}^{+}$ & P ppm \\
\hline $0-20$ & 52 & 33 & 15 & 3.7 & 5.4 & 11.1 & 3.9 & 0.88 & 0.23 & 124 \\
\hline $25-35$ & 77 & 17 & 6 & 1.1 & 5.6 & 13.6 & 10.5 & 0.76 & 0.38 & 6 \\
\hline
\end{tabular}

The ploughed layer of the experimental area is silty clay and the subsoil is heavy clay. Both the physical and the chemical characteristics of the soil show that it represents a clay soil fairly typical of southern Finland.

The average monthly temperature and precipitation during the growing season were on the experimental field the following:

Temperature, ${ }^{\circ} \mathrm{C} \quad$ Precipitation, mm

$\begin{array}{lrr}\text { May } & 10.0 & 24 \\ \text { June } & 14.1 & 15 \\ \text { July } & 16.4 & 24 \\ \text { August } & 15.6 & 111\end{array}$

In temperature the growing season was normal, but the precipitation was markedly lower than in normal years except in August.

The root studying method. The root investigations were limited to the $20 \mathrm{~cm}$ deep ploughed layer, as the main part of the root system of spring cereals is usually in this zone (SAlONEN 1949, WikLeRT 1960), and where the effect of fertilizer placement and irrigation would consequently be clearly in evidence.

The sampling boards (Figure 1) were made of $50 \times 50 \times 1.5 \mathrm{~cm}$ plywood board with $4^{\prime \prime}$ nails at a distance of $2.5 \mathrm{~cm}$ on an area of $20 \times 50 \mathrm{~cm}$. Before a sample was taken, a cardboard sheet was pressed on the nail board.

The root samples were collected from experimental plots immediately outside the area to be harvested. A $30 \mathrm{~cm}$ deep trench was dug with a spade in the soil. The vertical wall, perpendicular to the fertilizer and seed rows, was smoothed with the spade. The nail board was forced into this vertical wall so that the topmost nail row was level with the soil surface. The sample was removed by spade and the remaining soil was cut off outside the ends of the nails. Thus, the size of the soil block was $50 \times 20 \times 8.5 \mathrm{~cm}$. 


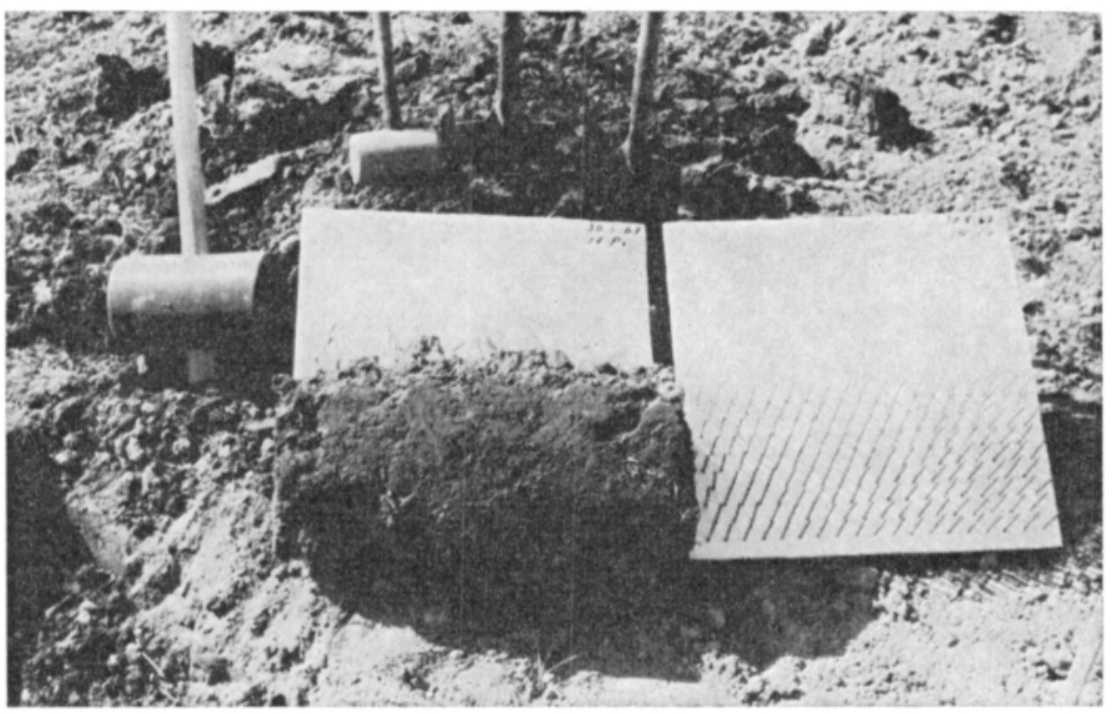

Figure 1. Nail boards used for taking root samples. On the left, board with a sample.

The soil was washed away from the sample with a soft jet of water so that the root system on the nail rows retained its original shape. The pump of the sprinkling equipment and the nozzles of a weed sprayer were used for washing. By means of these ten samples could be handled simultaneously. Since the soil was rather heavy clay, careful and thorough washing took a long time, about $10-15$ hours. At the last stage of the washing the pieces of straw and the roots of the weeds were removed with small forceps from the sample so that only the clean roots of the cereal remained.

The clean plant sample was then removed on the cardboard sheet from the nail board and was air-dried in the laboratory. The three middle rows of the plants were taken for analyses. The aerial parts and the underground parts were analysed separately. The root system was divided into layers, $2.5 \mathrm{~cm}$ in thickness. The root mass of every zone was weighed separately.

Root samples were taken at four dates, in total 56 samples:

June 1st, about one week after sprouting, 8 samples from trial 1,

June 20th, about four weeks after sprouting, 8 samples from trial 1 and 8 samples from trial 2,

July 10th, immediately after ear emergence, 16 samples from trial 2,

August 21st, at harvest stage, 16 samples from trial 2.

\section{Results}

Weights of different parts of plants. Figure 2 presents the air-dry weights of the" aerial and underground parts in each of the 56 samples as milligrams per plant. There is a very strong positive correlation between the aerial and the underground parts of an individual plant at every sampling date, in fact during the whole growing season. Figure 2 also shows that the root system has developed strongly in the early part of the summer, while the 


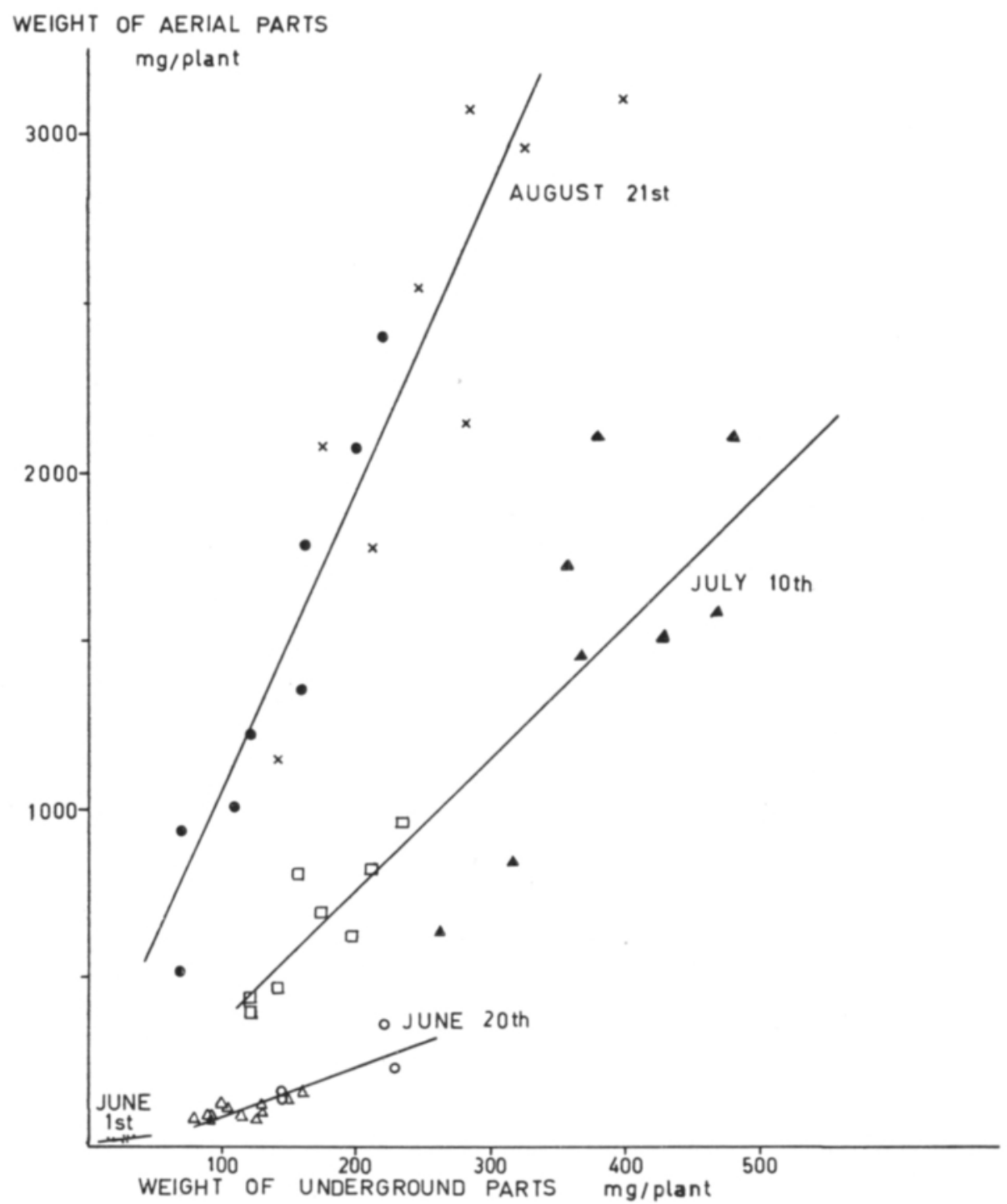

Figure 2. Relationship between the aerial $(\mathrm{Y})$ and the underground $(\mathrm{X})$ parts of individual plants at different dates (June 1st: $\bullet=$ wheat, $\mathrm{y}=0,45 \times+4,4, \mathrm{r}=0,700^{*}$, June 20th: $\mathrm{O}=$ wheat, $\triangle=$ barley, $\mathrm{y}=1,5 \times-64, \mathrm{r}=0,882^{* * *}$, July 10th: $\square=$ wheat, $\mathbf{\Delta}=$ barley, $\mathrm{y}=3,95 \times-26, \mathrm{r}=$ $0,883^{* * *}$, August 21st: $=$ wheat, $X=$ barley, $\left.y=9,0 \times+170, r=0,950 * * *\right)$.

greatest increase in weight of the aerial parts has taken place at the end of the summer when parts of the roots have already died.

A strong root system is in fact needed for obtaining good aerial growth. There is a close positive correlation also between the final grain yield and the root system, as may be seen from Figure 3. The correlation coefficient for wheat is as high as $0,966 * * *$.

More detailed specifications of the weights of the parts of plant are presented in Tables 1 and 2 as mean values of two replicates. 


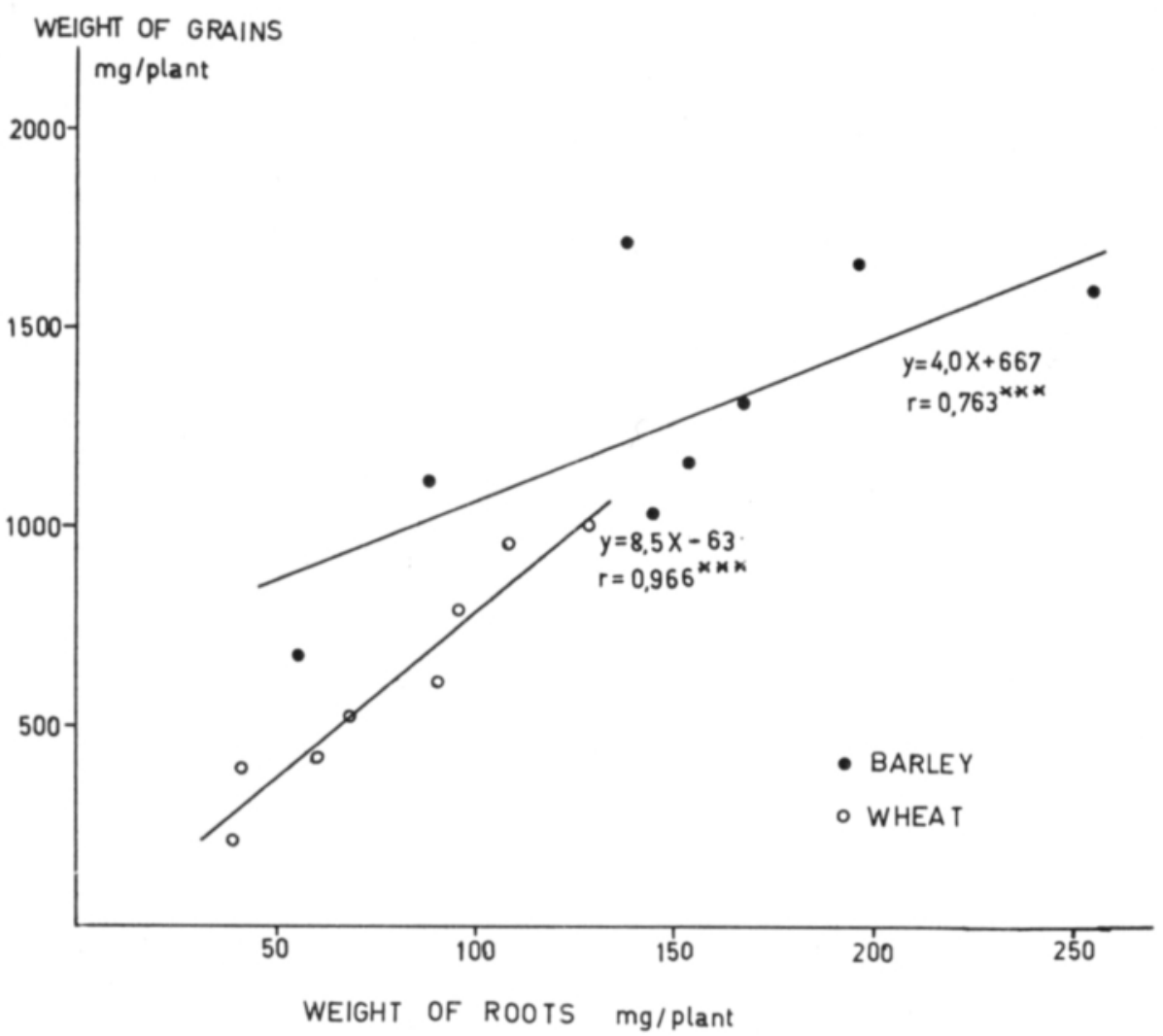

Figure 3. Relationship between the weight of the grains (Y) and weight of the roots (X) of wheat and barley.

The weight of the aerial parts of wheat shoots, taken on June 1st, was, on an average, $17 \mathrm{mg}$ per plant, and the mean weight of the underground parts $28 \mathrm{mg}$. Thus, the weight of the underground parts of plant one week old was nearly twice that of the aerial ones. Figure 4 shows that the root system had already by then reached the subsoil, and that it was vigorously widespread from the seed row. No effect of the fertilizing was found at that time either on the root system or on the aerial parts.

On June 20th, or about three weeks later, the aerial parts of a wheat plant had an average weight of $103 \mathrm{mg}$ and the underground ones $113 \mathrm{mg}$. At this stage the weight of shoots and roots was almost the same. The first stage of growth in barley was markedly faster, because the corresponding data were $227 \mathrm{mg}$ and $187 \mathrm{mg}$, respectively.

The effect on growth of fertilizing could be seen even visually by June 20th. Fertilizing had increased the weight of the aerial as well as the underground parts. In trial 1 there was no distinct difference between placement and surface dressing. This may be due chiefly to the fact that in trial 1 larger amounts of nutrient were applied than in trial 2. The solubility of the former fertilizer was, moreover, better so that even as surface dressing it supplied the demand during the early part of the summer. The effect of the placement therefore became visible only at the end of the summer. Further, it was found in later 
Table 1. Mean weights of shoots (a) and the underground parts (b) as mg/wheat plant in trial 1.

$\mathrm{F}_{0}=$ unfertilized

$\mathrm{F}_{\mathrm{b}}=$ fertilizer broadcast

$\mathrm{F}_{\mathrm{p} 12}=$ placement of fertilizer in rows with a distance of $12 \mathrm{~cm}$

$\mathrm{F}_{\mathrm{p}^{18}}=$ placement of fertilizer in rows with a distance of $18 \mathrm{~cm}$

\begin{tabular}{cccccccccc}
\hline & \multicolumn{4}{c}{ June 1st } & \multicolumn{5}{c}{ June 20th } \\
& $\mathrm{F}_{0}$ & $\mathrm{~F}_{\mathrm{p}}$ & $\mathrm{F}_{\mathrm{p}^{12}}$ & $\mathrm{~F}_{\mathrm{p}^{18}}$ & $\mathrm{~F}_{0}$ & $\mathrm{~F}_{\mathrm{p}}$ & $\mathrm{F}_{\mathrm{p}^{12}}$ & $\mathrm{~F}_{\mathrm{p}^{18}}$ \\
\hline $\mathrm{a}$ & 15 & 14 & 18 & 19 & 77 & 111 & 122 & 93 \\
$\mathrm{~b}$ & 29 & 27 & 29 & 29 & 86 & 121 & 116 & 123 \\
$\mathrm{a} / \mathrm{b}$ & 0.5 & 0.5 & 0.6 & 0.7 & 0.9 & 0.9 & 1.1 & 0.8 \\
\hline
\end{tabular}

Table 2. Mean weights of shoots (a) and the underground parts (b) as mg/plant in trial 2.

\begin{tabular}{|c|c|c|c|c|c|c|c|c|c|c|}
\hline & & $\begin{array}{l}F_{b} \\
F_{p}\end{array}$ & $\begin{array}{c}\text { fertilize } \\
"\end{array}$ & $\begin{array}{l}\text { broadc } \\
\text { placed }\end{array}$ & & $\begin{array}{l}\mathrm{K}_{0} \\
\mathrm{~K}_{2}\end{array}$ & $\begin{array}{l}\text { nirrigat } \\
\text { rrigated }\end{array}$ & & & \\
\hline & June & 20 th & & $\mathrm{Jul}$ & 10 th & & & Aug & $21 \mathrm{st}$ & \\
\hline & K & & & $\mathrm{C}_{0}$ & & 2 & & 0 & & 2 \\
\hline & $\mathrm{F}_{\mathrm{b}}$ & $F_{p}$ & $\mathrm{~F}_{\mathrm{b}}$ & $F_{p}$ & $\overline{F_{b}}$ & $F_{p}$ & $\overline{F_{b}}$ & $F_{p}$ & $\overline{F_{b}}$ & $F_{p}$ \\
\hline wheat & & & & & & & & & & \\
\hline a & 81 & 136 & 423 & 553 & 825 & 832 & 725 & 1282 & 1542 & 2095 \\
\hline b & 110 & 134 & 122 & 168 & 183 & 203 & 70 & 138 & 155 & 190 \\
\hline$a / b$ & 0.7 & 1.0 & 3.5 & 3.3 & 4.5 & 4.5 & 10.4 & 9.3 & 10.0 & 11.0 \\
\hline barley & & & & & & & & & & \\
\hline a & 158 & 296 & 742 & 1524 & 1618 & 1898 & 2122 & 1961 & 2572 & 2748 \\
\hline b & 149 & 224 & 288 & 417 & 391 & 413 & 269 & 246 & 228 & 284 \\
\hline$a / b$ & 1.1 & 1.3 & 2.6 & 3.7 & 4.1 & 4.6 & 7.9 & 8.0 & 11.3 & 9.7 \\
\hline
\end{tabular}

examinations that in trial 1 the placed fertilizer had not reached the desired depth of $7-8$ $\mathrm{cm}$. In trial 2 the placement of the fertilizer at a depth of $7-8 \mathrm{~cm}$ had considerably increased the growth of both wheat and barley: that of the aerial parts by an average of $77 \%$, and that of the underground parts by $36 \%$ compared with the effect of surface dressing.

On July 10th, samples were taken for the third time, again about three weeks after the previous sampling. The cereals had just formed ears. The average weight of an aerial part of a wheat plant was $657 \mathrm{mg}$ and that of the underground part $169 \mathrm{mg}$. Corresponding data with barley were $1445 \mathrm{mg}$ and $357 \mathrm{mg}$, respectively. Thus, the aerial and the underground plant masses of barley were more than twice those of wheat.

The effect of placement was again distinct. When the fertilizer was placed, the weight of the aerial part of a plant was, on an average, $38 \%$, and that of the underground part $25 \%$ higher than the corresponding figures from the plots with a surface dressing. 


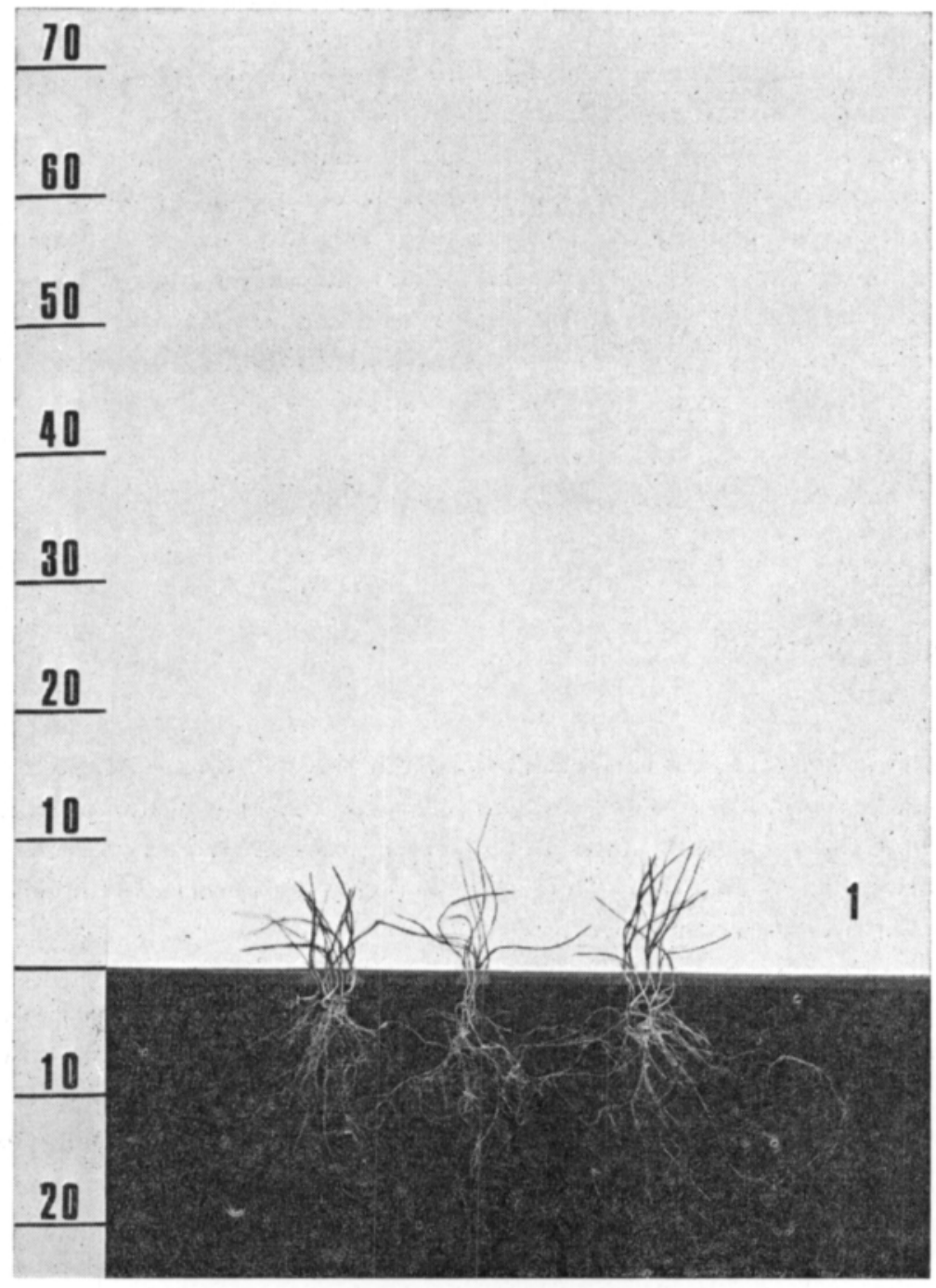

Figure 4. Root sample taken on June 1st from unfertilized plot.

The effect of irrigation, applied on June 15th and June 21st, was on July 10th quite marked. The aerial part of an irrigated plant was $72 \%$, and the underground part $27 \%$ larger than the corresponding parts of an unirrigated plant.

At the harvest stage, August 21st, the average weight of the aerial part of a wheat plant was $1286 \mathrm{mg}$, and that of the underground part $138 \mathrm{mg}$. The corresponding figures for barley were $2701 \mathrm{mg}$ and $257 \mathrm{mg}$. The aerial part had grown strongly since the previous date of sampling, but the weight of the underground part had decreased by about $25 \%$. Obviously, a part of the storage products of the root system had been translocated to the aerial organs of the plant, and a part of the secondary root system had decomposed.

The growth promoting effect of placement was still apparent at the harvest. The aerial part of a plant was, on an average, $28 \%$, and the underground part $34 \%$, heavier than 
the corresponding parts of plants which had received surfare dressing. It may be pointed out that the increase in the corresponding total grain yield due to the placement, was on an average $21 \%$ higher than that produced by surface dressing.

The average weight of the aerial part of an irrigated plant was at harvest stage $59 \%$, and that of the underground part $40 \%$ more than the corresponding weights of unirrigated plants. The effect of the irrigation may have been ever greater, since the samples were taken from the outside of the harvested plots and had received less water. Irrigation increased the grain yields of harvested plots in this trial by as much as $92 \%$.

The average ratio between shoots (a) and the underground parts (b) of a plant $(\mathrm{a} / \mathrm{b}$ in Table 2) was at different stages of development as follows:

$$
\text { June 20th July 10th August 21st }
$$

$\begin{array}{lllr}\text { surface dressing } & 0.9 & 3.7 & 9.9 \\ \text { placement } & 1.1 & 4.0 & 9.5 \\ & & & \\ \text { unirrigated } & - & 3.3 & 8.9 \\ \text { irrigated } & - & 4.4 & 10.5\end{array}$

The placement had not greatly influenced the shoot/root-ratio, although it had increased somewhat more the growth of the aerial parts than that of the underground parts during the first and the middle stages of the growing season. Irrigation seems to have increased both the aerial and the underground growth, the aerial growth relatively more than the underground growth, however.

Root distribution. The relative distribution of the root systems in the different zones of the ploughed layer is presented in Tables 3 and 4 . It is surprising that the main part of the root system in the ploughed layer lies during the whole growing season immediately beneath the sowing depth, or at a depth of $4-10 \mathrm{~cm}$. On the other hand parts of the roots have reached the subsoil already in the beginning of the growing season (Figure

Table 3. Relative distribution $(\%)$ of the root system of wheat in different soil layers in trial 1.

\begin{tabular}{|c|c|c|c|c|c|c|c|c|}
\hline \multirow{2}{*}{$\begin{array}{l}\text { Depth } \\
\mathrm{cm}\end{array}$} & \multirow[b]{2}{*}{$F_{0}$} & \multicolumn{3}{|c|}{ June 1st } & \multicolumn{4}{|c|}{ June 20th } \\
\hline & & $\mathrm{F}_{\mathrm{b}}$ & $F_{p 12}$ & $F_{p^{18}}$ & $F_{0}$ & $F_{b}$ & $F_{p^{12}}$ & $F_{p^{18}}$ \\
\hline $0-2.5$ & 4 & 3 & 1 & 12 & 1 & 8 & 1 & 5 \\
\hline $2.5-5.0$ & 35 & 53 & 31 & 44 & 19 & 32 & 42 & 44 \\
\hline $5.0-7.5$ & 29 & 25 & 42 & 23 & 22 & 22 & 28 & 18 \\
\hline $17.5-10.0$ & 15 & 10 & 15 & 11 & 13 & 12 & 9 & 11 \\
\hline $10.0-12.5$ & 9 & 5 & 7 & 8 & 12 & 9 & 6 & 8 \\
\hline $12.5-15.0$ & 4 & 2 & 3 & 1 & 11 & 7 & 7 & 7 \\
\hline $15.0-17.5$ & 4 & 2 & 1 & 1 & 11 & 6 & 4 & 4 \\
\hline $17.5-20.0$ & $\mathbf{0}$ & 0 & 0 & 0 & 11 & 4 & 3 & 3 \\
\hline
\end{tabular}


Table 4. Relative distribution of the root system of wheat and barley between the soil layers down to a depth of $20 \mathrm{~cm}$ in trial 2

$$
\begin{array}{ll}
\mathrm{F}_{\mathrm{b}}=\text { fertilizer broadcast } & \mathrm{K}_{0}=\text { unirrigated } \\
\mathrm{F}_{\mathrm{p}}=\$ \text { placed } & \mathrm{K}_{2}=\text { irrigated }
\end{array}
$$

\begin{tabular}{|c|c|c|c|c|c|c|c|c|c|c|}
\hline \multirow{3}{*}{$\begin{array}{l}\text { Depth } \\
\mathrm{cm}\end{array}$} & \multirow{2}{*}{\multicolumn{2}{|c|}{$\begin{array}{c}\text { June 20th } \\
\mathrm{K}_{0}\end{array}$}} & \multicolumn{4}{|c|}{ July 10th } & \multicolumn{4}{|c|}{ August 21st } \\
\hline & & & \multicolumn{2}{|c|}{$\mathrm{K}_{0}$} & \multicolumn{2}{|c|}{$\mathrm{K}_{2}$} & \multicolumn{2}{|c|}{$\mathrm{K}_{0}$} & \multicolumn{2}{|c|}{$\mathrm{K}_{2}$} \\
\hline & $\overline{\mathrm{F} b}$ & $\overline{\mathrm{Fp} p}$ & $\overline{\mathrm{F} b}$ & $\mathrm{~F} p$ & $\overline{\mathrm{F} b}$ & $\overline{\mathrm{F} p}$ & $\mathrm{~F} p$ & $\overline{\mathrm{F} p}$ & $\overline{\mathrm{F} b}$ & $\mathrm{Fp}$ \\
\hline \multicolumn{11}{|l|}{ Wheat } \\
\hline $0-2.5$ & 1 & 0 & 2 & 7 & 13 & 6 & 19 & 15 & 13 & 31 \\
\hline $2.5-5.0$ & 25 & 21 & 36 & 28 & 30 & 20 & 26 & 24 & 30 & 22 \\
\hline $5.0-7.5$ & 22 & 35 & 26 & 33 & 23 & 32 & 22 & 26 & 19 & 22 \\
\hline $7.5-10.0$ & 15 & 20 & 11 & 13 & 13 & 18 & 11 & 10 & 12 & 13 \\
\hline $10.0-12.5$ & 12 & 7 & 7 & 5 & 7 & 11 & 7 & 8 & 11 & 5 \\
\hline $12.5-15.0$ & 9 & 6 & 7 & 5 & 5 & 5 & 6 & 5 & 7 & 3 \\
\hline $15.0-17.5$ & 8 & 6 & 6 & 5 & 5 & 4 & 5 & 6 & 5 & 2 \\
\hline $17.5-20.0$ & 8 & 5 & 5 & 4 & 4 & 4 & 4 & 6 & 3 & 2 \\
\hline \multicolumn{11}{|l|}{ Barley } \\
\hline $0-2.5$ & 8 & 3 & 1 & 1 & 2 & 2 & 3 & 5 & 2 & 10 \\
\hline $2.5-5.0$ & 25 & 26 & 21 & 19 & 27 & 31 & 32 & 11 & 29 & 24 \\
\hline $5.0-7.5$ & 16 & 21 & 33 & 37 & 24 & 38 & 27 & 20 & 22 & 30 \\
\hline $7.5-10.0$ & 12 & 18 & 18 & 19 & 16 & 12 & 10 & 24 & 16 & 18 \\
\hline $10.0-12.5$ & 10 & 10 & 9 & 8 & 11 & 6 & 8 & 16 & 8 & 7 \\
\hline $12.5-15.0$ & 11 & 7 & 7 & 6 & 8 & 5 & 7 & 9 & 7 & 4 \\
\hline $15.0-17.5$ & 10 & 8 & 6 & 6 & 7 & 3 & 8 & 9 & 7 & 4 \\
\hline $17.5-20.0$ & 8 & 7 & 5 & 4 & 5 & 3 & 5 & 6 & 9 & 3 \\
\hline
\end{tabular}

4). The topmost $0-2.5 \mathrm{~cm}$ layer contained very few roots during the whole growing season, and in the middle and at the end of the summer the main part of these roots was buttress roots whose ability to uptake nutrients may be very slight.

On the basis of the following data representing the mean percentages of root mass in various layers, the stronger root system of barley (B) seems to have penetrated somewhat

\begin{tabular}{|c|c|c|c|c|c|c|}
\hline Depth & Jur & 20th & July & 10th & August & $21 \mathrm{st}$ \\
\hline $\mathrm{cm}$ & W & B & W & B & W & B \\
\hline $0-5$ & 24 & 31 & 35 & 26 & 45 & 29 \\
\hline $5-10$ & 46 & 38 & 42 & 49 & 34 & 42 \\
\hline $10-15$ & 17 & 19 & 15 & 15 & 13 & 17 \\
\hline $15-20$ & 13 & 12 & 8 & 10 & 8 & 12 \\
\hline
\end{tabular}
deeper into the ploughed layer than that of wheat $(\mathrm{W})$ :

The fertilizer placement had the expected effect on the mass of the root system also in its distribution in the different zones of the ploughed layer. In trial 2 the root system was distributed, on an average, in the surface dressing $\left(\mathrm{F}_{b}\right)$ plots and placement $\left(\mathrm{F}_{p}\right)$ plots as follows: 


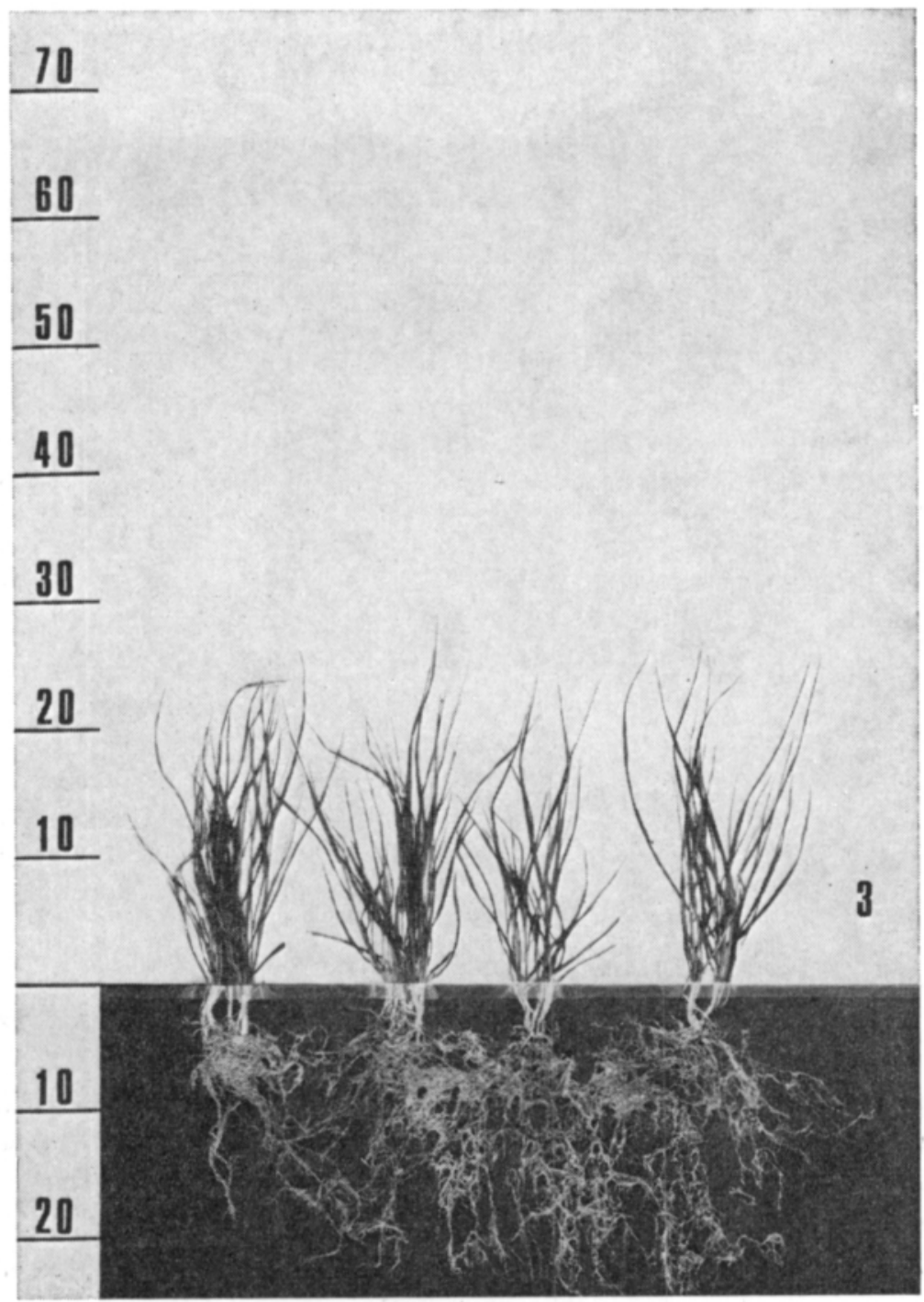

Figure 5. Root sample taken on June 20th. Fertilizer is placed.

Per cent of root mass

\begin{tabular}{|c|c|c|c|c|c|c|}
\hline Depth & Jur & 20th & Jul & 10th & August & 21st \\
\hline $\mathrm{cm}$ & $F_{b}$ & $\mathrm{~F}_{p}$ & $\mathrm{~F}_{b}$ & $\mathrm{~F}_{p}$ & $\mathrm{~F}_{b}$ & $\mathrm{~F}_{p}$ \\
\hline $0-5$ & 30 & 25 & 33 & 28 & 39 & 35 \\
\hline $5-10$ & 32 & 47 & 41 & 51 & 35 & 41 \\
\hline $10-15$ & 21 & 15 & 15 & 13 & 15 & 14 \\
\hline $15-20$ & 17 & 13 & 11 & 8 & 11 & 10 \\
\hline
\end{tabular}

The fertilizer placement increased considerably even the relative mass of the root system at placement depth $(5-10 \mathrm{~cm})$. This is apparent also in the photographs (Figures 


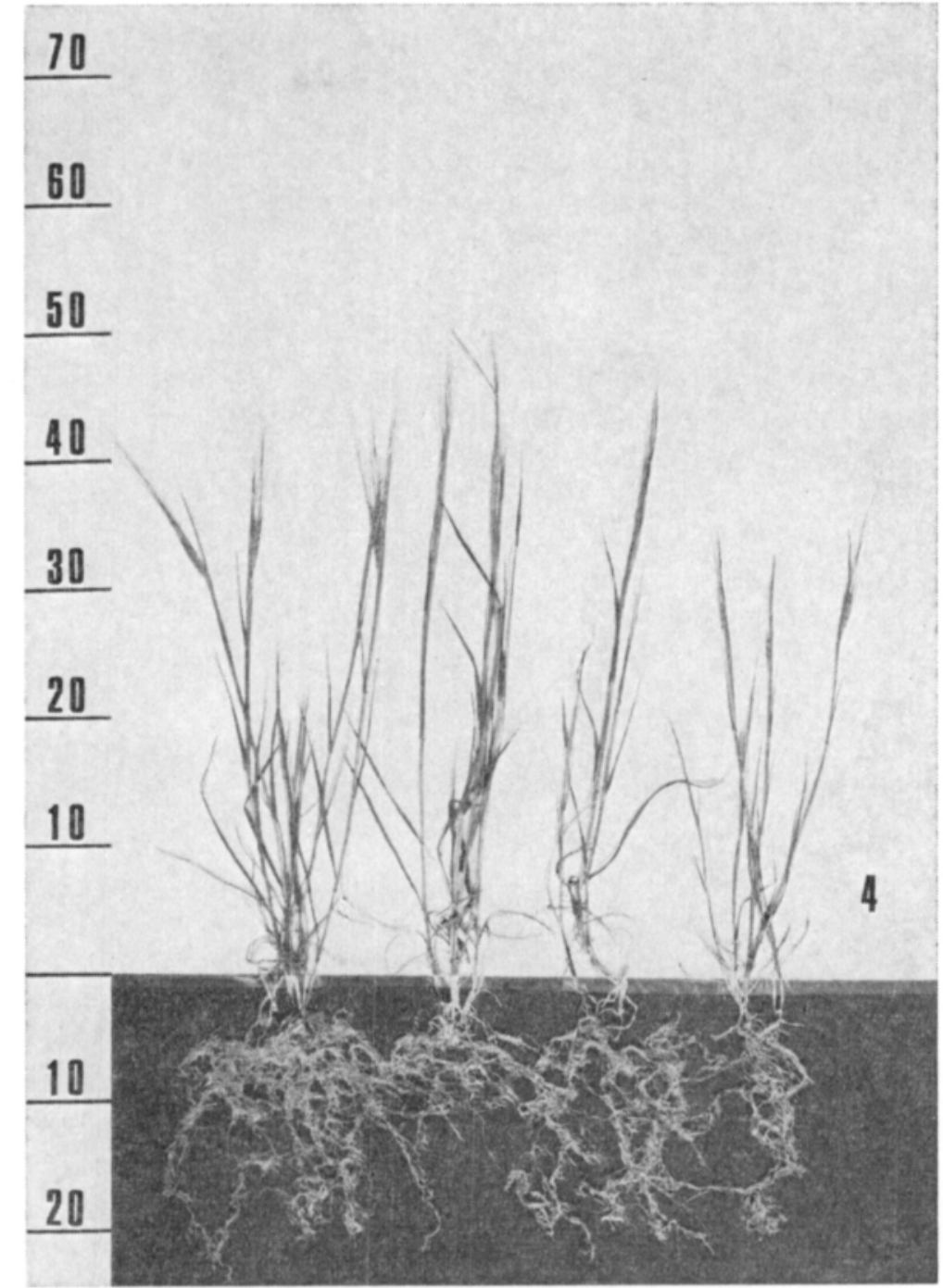

Figure 6. Root sample taken on July 10th. Fertilizer is surface dressed.

5-9) where dense root concentrations may be found around the fertilizer rows. Thus, roots have clearly sought their way to the fertilizer rows.

The average distribution of the root systems in the unirrigated $\left(\mathrm{K}_{0}\right)$ and irrigated $\left(\mathrm{K}_{2}\right)$ plants appears below:

Per cent of root mass

\begin{tabular}{lrrrr} 
Depth & \multicolumn{2}{c}{ July } & 10 th & \multicolumn{2}{c}{ August } & 21 st \\
cm & $\mathrm{K}_{0}$ & $\mathrm{~K}_{2}$ & $\mathrm{~K}_{0}$ & $\mathrm{~K}_{2}$ \\
& & & & \\
$0-5$ & 29 & 33 & 34 & 40 \\
$5-10$ & 48 & 44 & 37 & 38 \\
$10-15$ & 13 & 14 & 17 & 13 \\
$15-20$ & 10 & 9 & 12 & 9
\end{tabular}




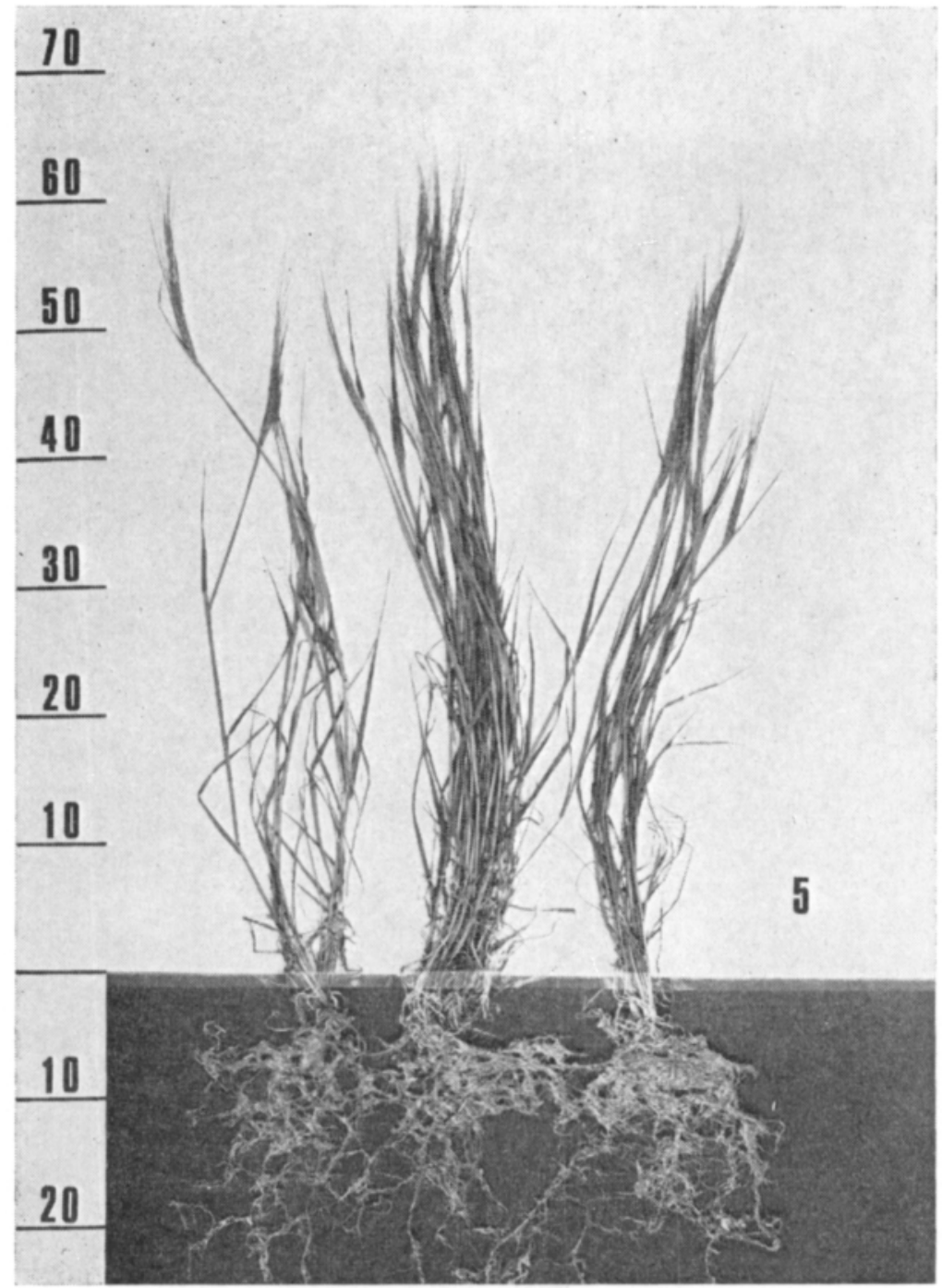

Figure 7. Root sample taken on July 10th. Fertilizer is placed.

It seems that irrigation had only a slight effect on the distribution of the root system. It is evident that irrigation has increased the root mass to the same extent at the different depths of the ploughed layer.

\section{Discussion}

The results of the study show that good aerial growth demands a vigorous development of the root system. Cultivation measures that increase root growth in the beginning and in the middle of the summer also increase the aerial growth and the grain yield.

Placement of fertilizer and irrigation are ways by which the growth of root systems can be increased. A stronger root system is able to give a better supply of nutrients to the aerial parts of a plant in this way making possible a higher yield. The conclusion that the effect 


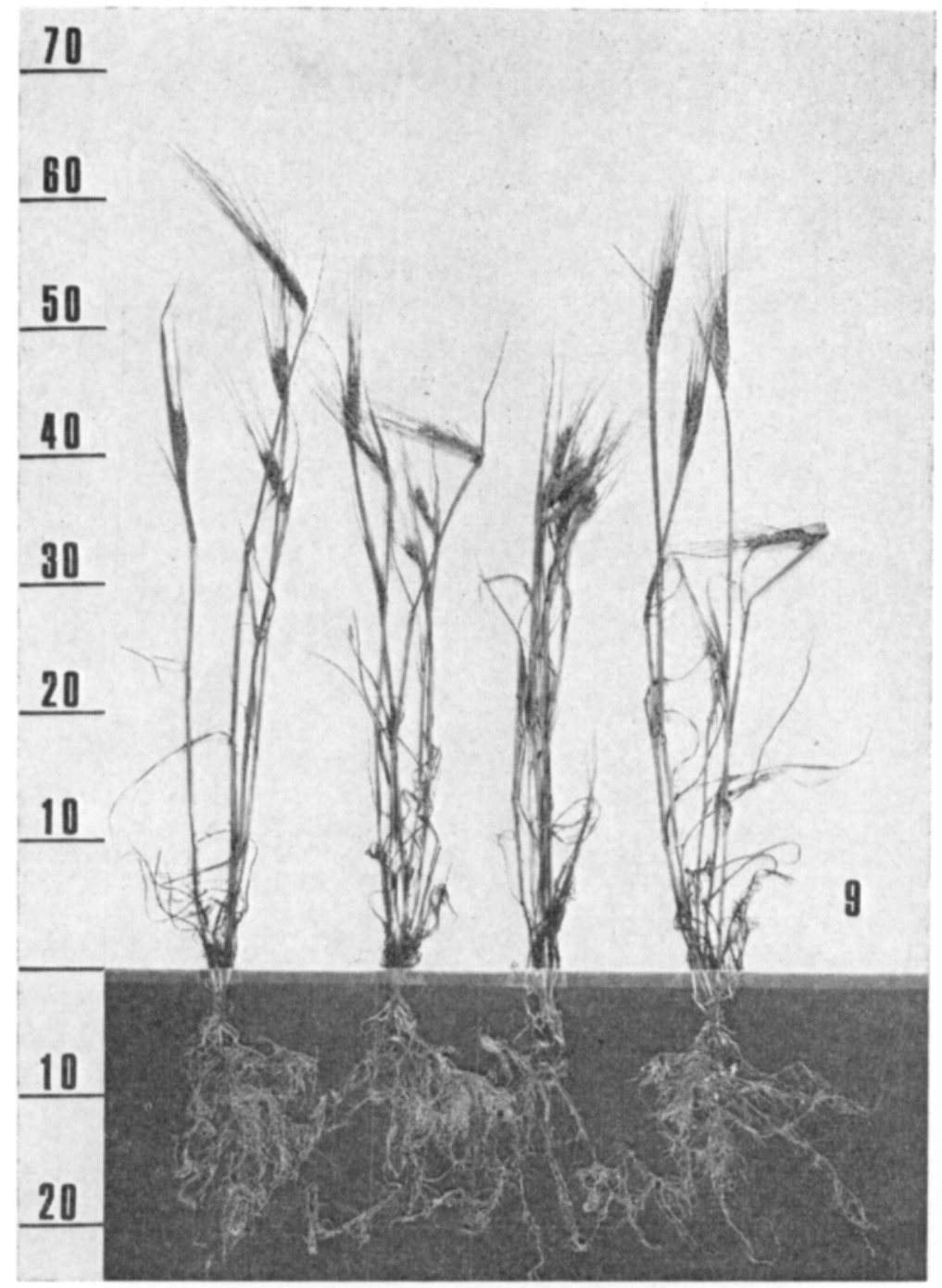

Figure 8. Root sample taken on August 21st. Fertilizer is placed, unirrigated.

of placement and irrigation depends mainly on a better recovery of nutrients has been reached also by other research workers (Elonen et al, 1967, AurA 1967). It is in fact not a question of lack of water as such, but of the roots taking up water particularly from the soil layer where nutrients are located.

Judging by the present results it is important to place the fertilizer at a certain depth, but it is of no consequence whether the fertilizer row is located directly beneath the seed row or between two seed rows.

Some unpublished results of field trials indicate that the fixed distance between the seed and fertilizer coulters (an inch aside and an inch downwards) has no particular effect if compared with a separate seed and fertilizer placement. The row width of fertilizer coulters may in fact vary within very wide limits, e.g. $12-18 \mathrm{~cm}$, without it affecting the 


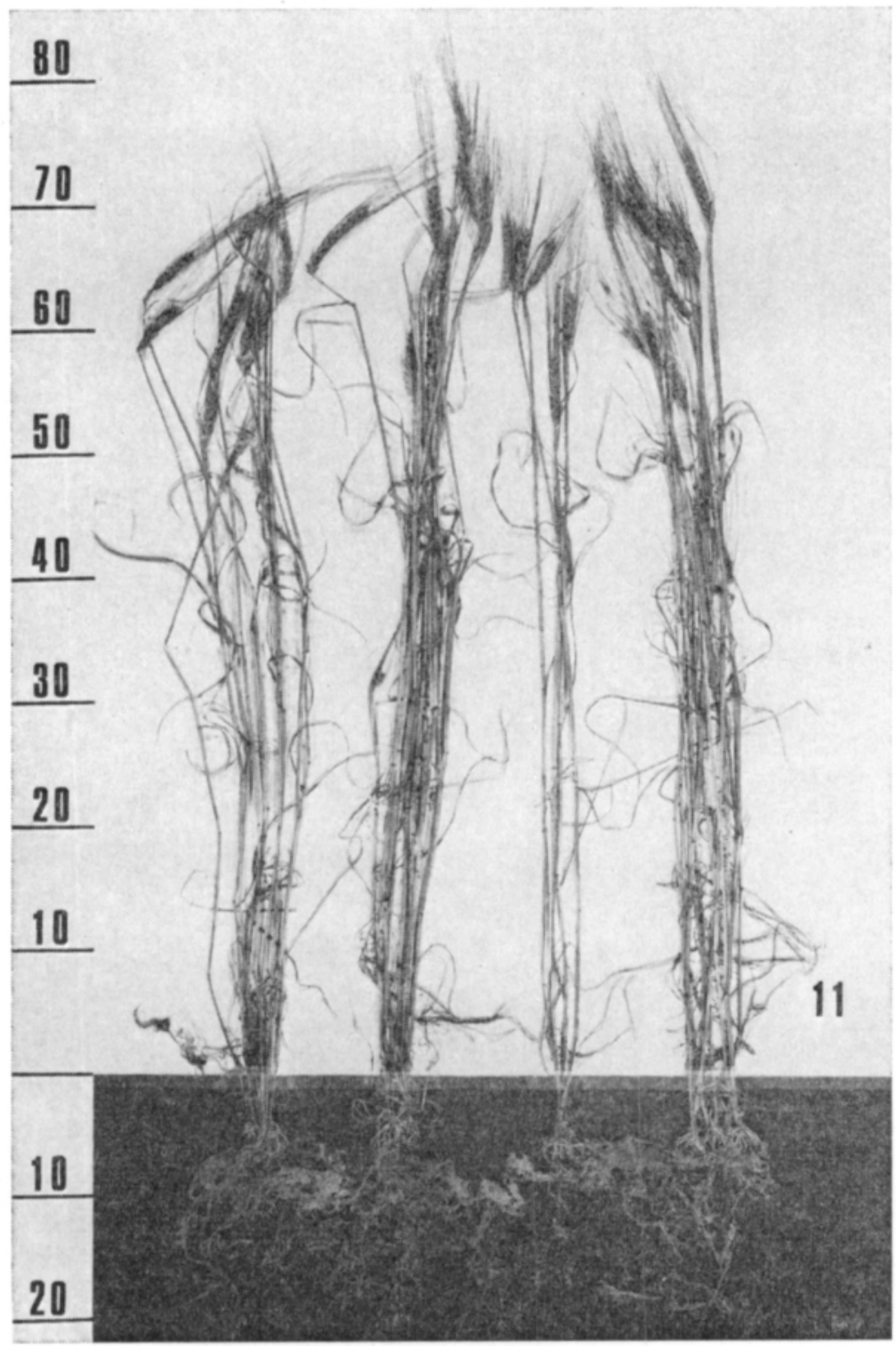

Figure 9. Root sample taken on August 21st. Fertilizer is placed, irrigated.

yield. The results may be explained on the basis of the present root investigation. The roots of spring cereals are able to grow surprisingly rapidly around the fertilized row, although the fertilizer may lie rather far from the seed row. This is proved by the well developed root systems of sprouts one week old (Figure 4) and the strong root concentrations around fertilized rows, even at the harvest stage (Figures 5-9).

An optimum depth of placement cannot be determined merely on the basis of the results obtained by this study. It would be technically easiest to use as low a depth of placement as possible so as to limit friction. The chance of clogging and breaking of the fertilizer drill 
would likewise be slight. According to the results of root distribution, the most profitable depth would be $5-10 \mathrm{~cm}$. A depth lower than $5 \mathrm{~cm}$ may not be recommended, since a part of the roots in this layer consists of buttress roots and the layer without any roots reaches deeper between the seed rows (Figures 5-9). The right placement depth also depends on the soil and on the differences in root distribution in the ploughed layer caused by the annual variation in the moisture conditions during the spring and early summer.

\section{S u m m a r y}

In 1967, two large field trials were performed on clay soil in South Finland in order to obtain detailed information on the effect of fertilizer placement and sprinkler irrigation on spring cereals. In the present paper the results of the root investigations, carried out in connection with these trials, are reported.

Fifty-six root samples were taken on four dates during the growing season. The roots in the soil blocks, taken perpendicularly to the fertilizer and seed rows, retained their original distribution during washing and drying.

The growth of the roots was stronger than the growth of the shoots of plants in the early part of the summer, but at the end of the summer, when the main yield above ground developed, the weight of the roots no longer increased, in fact it had decreased. There was a close correlation between the weights of roots and the weights of the shoots of plants during the whole growing season. A particularly high correlation was found between the root system and the grain yield.

Fertilizer placement and irrigation increased both the growth of roots and the growth of shoots of plants. The relative increases produced by the placement of fertilizer were equal in the weights of roots and in the weights of aerial parts, but irrigation increased the weight of aerial parts to a relatively greater extent than the weight of roots.

The distribution of the roots in the top soil was somewhat unexpected. A part of the roots reached the subsoil quite early in the growing season. On the other hand, the main part of the root system in the ploughed layer lay, during the whole growing season, immediately beneath the sowing depth, or at a depth of $4-10 \mathrm{~cm}$. The topmost layer, i.e. the layer above the sowing depth, contained very few roots during the entire growing season, and the main part of these roots consisted of buttress roots, whose capacity for taking up nutrients may be very slight.

Irrigation had only a slight effect on the distribution of the root system, while the effect of fertilizer placement was very distinct. The roots clearly sought their way to the fertilized rows, also in cases where the distance between fertilized and sowing rows was remarkably great.

On the basis of the results it was concluded that it is important to place the fertilizer at a convenient depth, 5-10 cm, when spring cereals are in question. The horizontal distance between seed rows and fertilized rows appeared to be of less importance.

A c knowledgements. The authors wish to thank the Finnish Research Institute of Agricultural Engineering for technical help and co-operation in the field work, as well as the Norsk Hydro-Elektrisk Kvaelstofaktieselskap for economic assistance. 


\title{
REFERENCES
}

Aura, E. 1967. Effect of the placement of fertilizer on the development of spring wheat. J. Sci. Agr. Soc. Finland 39: 148-155.

Elonen, P. \& Nieminen, L. \& KarA, O. 1967. Sprinkler irrigation on clay soils in Southern Finland. Ibid 39: 67-98.

Heinonen, R. \& Nieminen, L. 1961. Väkilannoitteiden rivikylvö. Summary: Trials on placement of fertilizer. Maat. ja koetoim. 15: 7-14.

LARPEs, G. 1966. Rivilannoituksen vaikutus kevätviljoissa. Summary: The effect of fertilizer placement in spring cereals. Ibid 21: 14-20.

— — 1967. Kevätviljojen syvälannoitus. Summary: Deep fertilization in spring cereals. Ibid 21: $20-25$.

Nieminen, L. \& Kara, O. \& Elonen, P. 1967. Kokemuksia sijoituslannoituksesta. Summary: Trials on placement of fertilizer. Ibid 21: 42-49.

Pohjanhermo, O. \& Heinonen, R. 1960. The effect of irrigation on root development, water use, nitrogen uptake and yield characteristics of several barley varieties. Acta Agr. Fenn. 95,6: 1-18.

SAlONEN, M. 1949. Tutkimuksia viljelykasvien juurten sijainnista Suomen maalajeissa. Summary: Investigations of the root positions of field crops in the soils of Finland. Ibid 70,1: 1-91.

WikLert, P. 1960. Studier av rotutvecklingen hos några nyttoväxter med särskild hänsyn till markstrukturen. Grundförbättring 3: 113-148.

\section{SELOSTUS}

\section{SIJOITUSLANNOITUKSEN JA SADETUKSEN VAIKUTUS KEVÄTVILJOJEN KEHITTYMISEEN JUURISTOTUTKIMUSTEN VALOSSA}

\author{
Jorma Kähäri ja PaAvo Elonen
}

Helsingin Yliopiston maanviljelyskemian laitos

1967 perustettiin savimaalle Espoon Pakankylään kaksi laajaa kenttäkoetta, joiden avulla pyrittiin saamaan yksityiskohtaista tietoutta sijoituslannoituksen ja sadetuksen vaikutustavoista kevätviljoihin. Tässä julkaisussa on esitetty näiden kenttäkokeiden yhteydessä suoritettujen juuristotutkimusten tulokset.

Neljänä ajankohtana otettiin yhteensä 56 juuristonäytettä siten, että juurten jakautuminen kylvö- ja lannoiterivejä vastaan kohtisuoraan otetuissa maasärmiöissä säilyi luonnonmukaisena pesu- ja kuivausvaiheiden aikana.

Juuriston kasvu oli alkukesällä voimakkaampaa kuin maanpäällisten kasvinosien kasvu, mutta loppukesällä, jolloin pääosa maanpäällisestä sadosta muodostui, juuriston paino ei enää lisääntynyt, vaan alkoi päinvastoin vähetä. Juuriston painon ja maanpäällisten kasvinosien painon välillä vallitsi selvä positiivinen riippuvuussuhde koko kasvukauden ajan. Erityisen selvänä korrelaatio tuli esiin juuriston ja jyväsadon välillä.

Sijoituslannoitus ja sadetus lisäsivät sekä juuriston että maanpäällisten kasvinosien painoa, sijoituslannoitus molempia suhteellisesti yhtä paljon, sadetus suhteellisesti enemmän maanpäällistä kasvua.

Juuriston sijoittuminen muokkauskerrokseen oli jossain määrin yllätyksellistä. Toisaalta viikon ikäisen oraan juuristo oli jo hämmästyttävän hyvin kehittynyt ulottuen jankkoon asti. Toisaalta kuitenkin pääosa juuristosta sijaitsi koko kasvukauden ajan välittömästi siemenen kylvösyvyyden alapuolella olevassa maakerroksessa 4-10 cm:n syvyydessä. Siemenen kylvösyvyyden yläpuolella oleva maan pintakerros oli käytännöllisesti katsoen juuretonta. Se sisälsi lähinnä vain tukijuuria, joiden merkitys ravinteiden saannin kannalta lienee vähäinen.

Juuriston sijaintiin sadetus ei näyttänyt mainittavasti vaikuttaneen, mutta sijoituslannoituksen vaikutus oli sitäkin selvempi. Pääosa muokkauskerroksen juuristosta oli hakeutunut lannoitenauhojen ympärille sijoitussyvyyteen, vaikka lannoiterivit olisivat sijainneet melko etäälläkin siemenriveistä.

Tulosten perusteella pääteltiin, että kevätviljoille on tärkeätä sijoittaa lannoite sopivaan syvyyteen, 5-10 cm:iin. Siemenrivien ja lannoiterivien välinen etäisyys sivusuunnassa näytti sen sijaan olevan vähemmän merkityksellistä. 